\title{
Antimicrobial, Antioxidant and Cytotoxic Activities and Phytochemical Screening of Some Yemeni Medicinal Plants
}

\author{
Ramzi A. A. Mothana ${ }^{1}$, Salah A. A. Abdo을 Sidgi Hasson², Faisal M. N. Althawab², \\ Sama A. Z. Alaghbari ${ }^{2}$ and Ulrike Lindequist ${ }^{3}$
}

${ }^{1}$ Department of Pharmacognosy, Faculty of Pharmacy, Sana'a-University, PO Box 33039, ${ }^{2}$ Institute of Pharmacy, College of Medical science, University of Science and Technology, Sana'a, Yemen and ${ }^{3}$ Department of Pharmaceutical Biology, Institute of Pharmacy, Ernst-Moritz-Arndt-University, Greifswald, F-L-Jahn Str. 15a, D-17487 Greifswald, Germany

\begin{abstract}
The traditional medicine still plays an important role in the primary health care in Yemen. The current study represents the investigation of 16 selected plants, which were collected from different localities of Yemen. The plants were dried and extracted with two different solvents (methanol and hot water) to yield 34 crude extracts. The obtained extracts were tested for their antimicrobial activity against three Gram-positive bacteria, two Gram-negative bacteria, one yeast species and three multiresistant Staphylococcus strains using agar diffusion method, for their antioxidant activity using scavenging activity of DPPH radical method and for their cytotoxic activity using the neutral red uptake assay. In addition, a phytochemical screening of the methanolic extracts was done. Antibacterial activity was shown only against Gram-positive bacteria, among them multiresistant bacteria. The highest antimicrobial activity was exhibited by the methanolic extracts of Acalypha fruticosa, Centaurea pseudosinaica, Dodonaea viscosa, Jatropha variegata, Lippia citriodora, Plectranthus hadiensis, Tragia pungens and Verbascum bottae. Six methanolic extracts especially those of A. fruticosa, Actiniopteris semiflabellata, $D$. viscosa, $P$. hadiensis, $T$. pungens and $V$. bottae showed high free radical scavenging activity. Moreover, remarkable cytotoxic activity against FL-cells was found for the methanolic extracts of A. fruticosa, Iris albicans, L. citriodora and T. pungens. The phytochemical screening demonstrated the presence of different types of compounds like flavonoids, terpenoids and others, which could be responsible for the obtained activities.
\end{abstract}

Keywords: antibacterial-cytotoxicity-medicinal plants-radical scavenging-Yemen

\section{Introduction}

Plant-derived drugs remain an important resource, especially in developing countries, to combat serious diseases. Approximately $60-80 \%$ of the world's population still relies on traditional medicines for the treatment of common illnesses $(1,2)$. Traditional remedies have a long-standing history in many locations in Yemen and

For reprints and all correspondence: Ramzi Mothana, Department of Pharmacognosy, Faculty of Pharmacy, Sana'a-University, PO

Box 33039, Sana'a, Yemen. Tel: +9671-225097; Fax: +9671-374682;

E-mail: r_mothana@yahoo.com continue to provide useful and applicable tools for treating ailments (3-5). Nevertheless, little scientific research was done to investigate the plants of Yemen used in herbal medicine. In the course of our investigations we found that several plants of the Yemeni ethnomedicine possess really interesting biological activities, which could be of interest for all parts of the world $(6-11)$. The aim of this work was to continue these investigations and to determine the antimicrobial, antioxidant and cytotoxic activities of till now uninvestigated medicinal plants collected from different locations of Yemen. In this study, a total of 34 extracts prepared from

This is an Open Access article distributed under the terms of the Creative Commons Attribution Non-Commercial License (http://creativecommons.org/ licenses/by-nc/2.0/uk/) which permits unrestricted non-commercial use, distribution, and reproduction in any medium, provided the original work is properly cited. 
16 plants have been determined for their antibacterial and antifungal activity by means of the agar diffusion method, antioxidant activity using scavenging activity of DPPH radical method and cytotoxic activity using the neutral red uptake assay. Furthermore, a phytochemical screening of the methanolic extracts was performed.

The activities have been selected because of their great medicinal relevance. Within the recent years, infections have increased to a great extent and resistance against antibiotics becomes an ever-increasing therapeutic problem (12). Because natural products of higher plants may give a new source of antimicrobial agents, there are many research groups that are now engaged in medicinal plants research (13-15).

In the last years, interest in the antioxidant activity of plant extracts has become larger and very important (16-18) due to the fact that free radicals e.g. reactive oxygen species (ROS) can be responsible for various diseases, e.g. heart diseases, stroke, arteriosclerosis and cancer, as well as for aging process (19).

\section{Methods}

\section{Plant Materials}

The plants were collected from different localities of Yemen in July 2005 and identified at the Pharmacognosy Department, Faculty of Pharmacy, Sana'a University. Part of the identification of the investigated plants was done by Priv.-Doz. Dr Peter Koenig, at the botanical garden, Ernst-Moritz-Arndt-University, Greifswald, Germany. Voucher specimens were deposited at the Pharmacognosy Department, Faculty of Pharmacy, Sana'a University.

\section{Extraction of Plant Material}

The air-dried and powdered plant materials ( $10 \mathrm{~g}$ of each) were extracted with $400 \mathrm{ml}$ methanol $\left(\mathrm{CH}_{3} \mathrm{OH}\right)$ by using a Soxhlet apparatus for $8 \mathrm{~h}$. The residue was dried over the night and then extracted with $250 \mathrm{ml}$ water $\left(\mathrm{H}_{2} \mathrm{O}\right)$ by using a shaking water-bath at $70^{\circ} \mathrm{C}$ for $2 \mathrm{~h}$. The extraction with water was repeated thrice. The waterfiltrates were mixed together. The obtained methanolic and water extracts were filtered and evaporated by using a rotary evaporator and freeze dryer, respectively to give the crude dried extract. The dried extracts were stored at $-20^{\circ} \mathrm{C}$ until used.

\section{Test Organisms}

The following microorganisms were used as test organisms: Staphylococcus aureus (ATCC 6538), Bacillus subtilis (ATCC 6059), Micrococus flavus (SBUG 16), Escherichia coli (ATCC 11229), Pseudomonas aeruginosa (ATCC 27853) and Candida maltosa (SBUG). In addition, three multiresistant Staphylococcus strains namely, S. epidermidis 847, S. haemolyticus 535 and $S$. aureus North German Epidemic Strain (supply from the Institute of Hygiene of Mecklenburg-Vorpommern, Greifswald, Germany) were also applied as test organisms.

\section{Antimicrobial Assay}

The disc-diffusion assay (20) was used to determine the antimicrobial activity of the investigated extracts. Nutrient agar (OXOID LTD, Basingstoke, Hampshire, England) was prepared by dissolving of $27 \mathrm{gl}^{-1}$ in water. The sterile nutrient agar was inoculated with microbial cells $(200 \mu 1$ of microbial cell suspension in $20 \mathrm{ml}$ agar medium) and poured into sterile petri dishes. Sterile filter paper discs of $6 \mathrm{~mm}$ diameter (Schleicher and Schuell, ref. No. 10321260, lot. DG0274-1) were impregnated with $20 \mu \mathrm{l}$ of the extract solution (equivalent to $4 \mathrm{mg}$ of the dried extract). The paper discs were allowed to evaporate and after that placed on the surface of the inoculated agar plates. Plates were kept for $2 \mathrm{~h}$ in refrigerator to enable prediffusion of the extracts into the agar. Then, the plates were incubated overnight $(18 \mathrm{~h})$ at $37^{\circ} \mathrm{C}$. In contrast, M. flavus was incubated at room temperature for $48 \mathrm{~h}$ and C. maltosa was incubated at $28^{\circ} \mathrm{C}$ for $48 \mathrm{~h}$. Ampicillin, gentamicin and amphotericin B were used as positive control. Negative controls were performed using paper discs loaded with $20 \mu$ of organic solvents (chloroform and methanol). At the end of the incubation period the antibacterial activity was evaluated by measuring the inhibition zones (diameter of inhibition zone plus diameter of the disc). An inhibition zone of $14 \mathrm{~mm}$ or more was considered as high antibacterial activity.

\section{Determination of Antioxidant Activity}

\section{Scavenging Activity of DPPH Radical}

In order to measure antioxidant activity, DPPH free radical scavenging assay was used. This assay measures the free radical scavenging capacity of the investigated extracts. DPPH is a molecule containing a stable free radical. In the presence of an antioxidant which can donate an electron to DPPH, the purple color which is typical for free DPPH radical decays, and the change in absorbency at $517 \mathrm{~nm}$ is followed specrophotometrically. This test could provide information on the ability of a compound to donate a hydrogen atom, on the number of electrons a given molecule can donate, and on the mechanism of antioxidant action. The method was carried out as described by Brand et al. (21). The methanolic and aqueous extracts were redissolved in methanol and $5 \%$ ethanol, respectively and various concentrations $\left(10,50,100,500\right.$ and $\left.1000 \mu \mathrm{g} \mathrm{ml}^{-1}\right)$ of each extract were used. The assay mixture contained in total volume of $1 \mathrm{ml}, 500 \mu \mathrm{l}$ of the extract, $125 \mu \mathrm{l}$ prepared DPPH ( $1 \mathrm{mM}$ in methanol) and $375 \mu \mathrm{l}$ solvent (methanol or $5 \%$ 
Table 1. List of plants screened

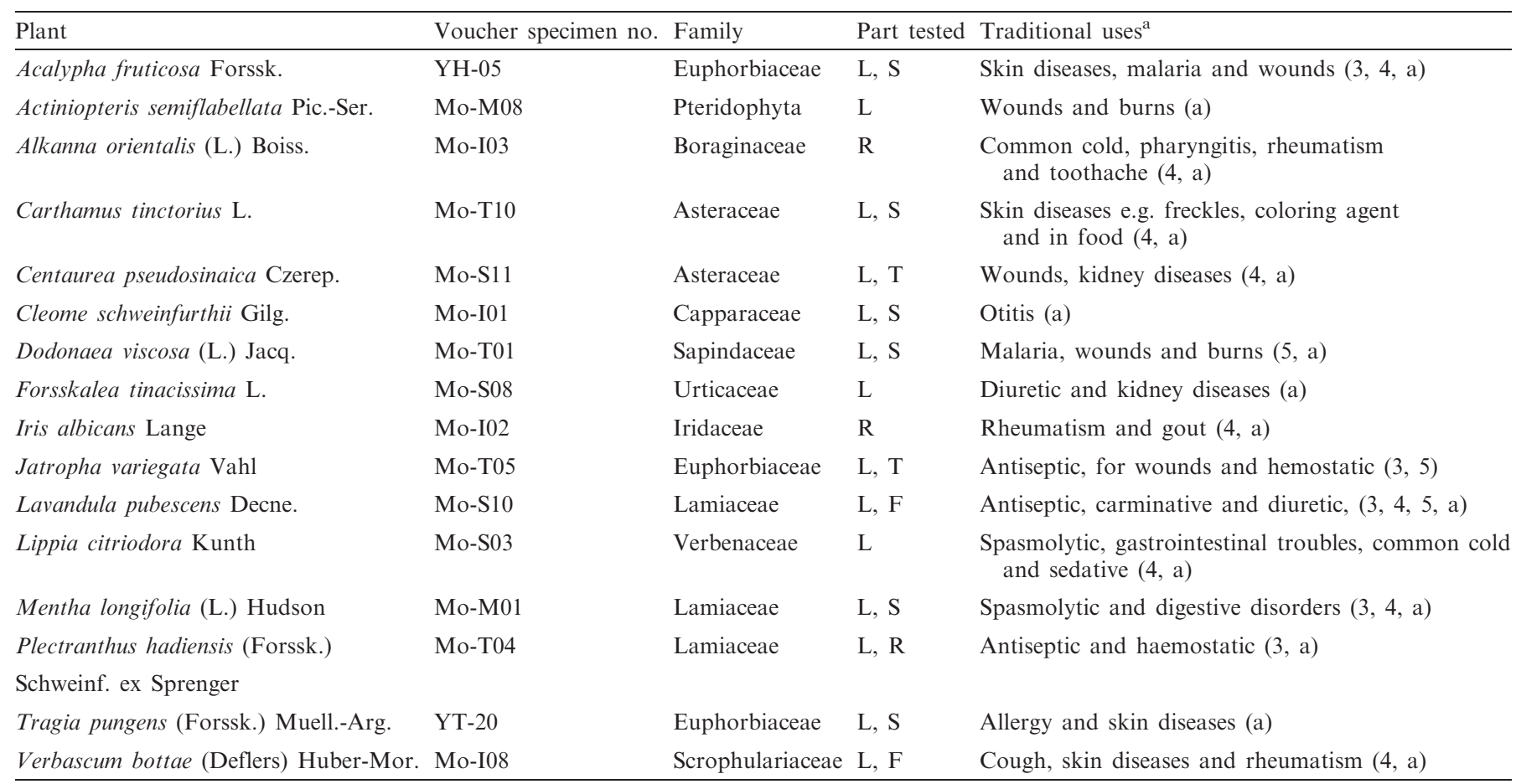

F: Flower, L: Leaves, R: Roots or rhizomes, S: Stems, T: Fruits.

${ }^{a}$ Information of traditional use has been taken from native people.

ethanol). After $30 \mathrm{~min}$ incubation at $25^{\circ} \mathrm{C}$, the decrease in absorbance was measured at $\lambda=517 \mathrm{~nm}$. The radical scavenging activity was calculated from the equation:

Percentage of radical scavenging activity $=$

$$
\left(\mathrm{Abs}_{\text {control }}-\mathrm{Abs}_{\text {sample }}\right) / \mathrm{Abs}_{\text {control }} \times 100
$$

\section{Cytotoxicity Assay}

The cytotoxicity of the investigated extracts was measured by the neutral red uptake assay (22) using FL-cells, a human amniotic epithel cell line. Only living cells are able to manage the active uptake of neutral red. The effect of the plant extracts on the proliferation of the FL-cells was determined in 96-well tissue culture plates. Confluent monolayers were incubated with different concentrations (serial dilutions) in medium for $72 \mathrm{~h}$. The $50 \%$ cellinhibitory concentration $\left(\mathrm{IC}_{50}\right)$ was determined.

\section{Phytochemical Screening of the Methanolic Extracts}

The screening of chemical constituents was carried out with the methanol extracts using chemical methods and thin-layer chromatography (TLC) according to the methodology given in (23).

\section{Results}

This article describes the antimicrobial, antioxidant and cytotoxic activities of a number of plants from different localities used in Yemeni traditional medicine. A total of
34 extracts representing 16 plant species belonging to 11 families were submitted in the screening. Table 1 shows the botanical names, plant part used and the traditional uses of the plants in the collected areas.

\section{Characteristics of Plants}

The results of the antimicrobial activity of the investigated extracts are shown in Table 2. The antimicrobial activity of the studied plant extracts was exhibited mainly against the Gram-positive bacteria. None of the extracts showed any activity against Gram-negative bacteria. It was interesting to note that the multiresistant Staphylococcus strains showed more sensitivity to the investigated extracts than the other antibiotic susceptible Gram-positive bacteria. Generally, among the investigated extracts the methanolic extracts exhibited the highest antibacterial effect. The most pronounced activity with inhibition zones more than $14 \mathrm{~mm}$ was shown by the methanolic extracts of Acalypha fruticosa, Dodonaea viscosa, Jatropha variegata, Lippia citriodora, Plectranthus hadiensis (roots) and Tragia pungens (Table 2). The majority of the hot aqueous extracts of the antibacterial active plants did not express any activity or exhibited only low activity. It is remarkable that no extract showed any antifungal activity against $C$. maltosa.

\section{Antioxidant Activity}

The methanol extracts of six plants namely, A. fruticosa, A. semiflabellata, D. viscosa, P. hadiensis, T. pungens and 
Table 2. Results of the antimicrobial activity of the investigated plants in agar diffusion method

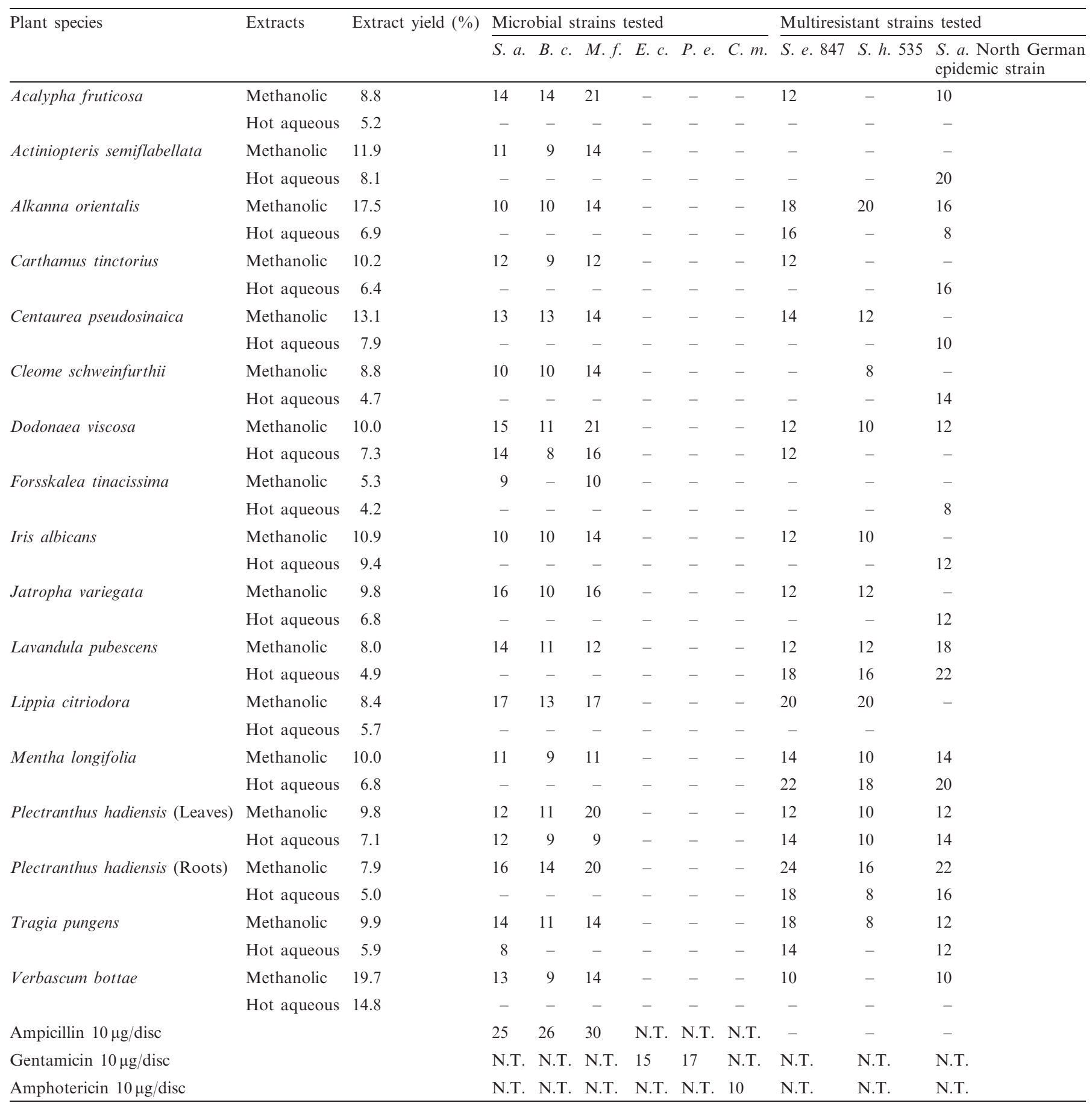

S. a., Staphylococcus aureus ATCC 6538; B. c., Bacillus subtilis ATCC 6059; M.f., Micrococcus flavus SBUG 16; E. c., Escherichia coli ATCC 11229; P. e., Pseudomonas aeruginosa ATCC 27853; C. m., Candida maltosa SBUG; S. e. 847, multiresistant Staphylococcus epidermidis; S. h. 535, multiresistant Staphylococcus haemolyticus; S. a. North German species, multiresistant Staphylococcus aureus; -, no activity; N.T., not tested; Inhibition zones including the diameter of the paper disc $(6 \mathrm{~mm})$.

$V$. bottae showed a high effective free radical scavenging in the DPPH assay. These extracts exhibited a remarkable antioxidant effect at low concentrations. So the methanolic extracts of $A$. fruticosa and $T$. pungens exhibited at $10 \mu \mathrm{g} \mathrm{ml}^{-1}$ an extraordinary antioxidant effect $(43 \%$ and $54 \%$ successively) whereas the ascorbic acid showed at this concentration an effect of $45 \%$ (Table 3). A. semiflabellata, D. viscosa and P. hadiensis started to exhibit a high effective free radical scavenging at $50 \mu \mathrm{g} \mathrm{ml}^{-1}(55,50$ and $54 \%$, respectively). The water extracts of all investigated plants were only weak active. The free radical scavenging effect ranged between 10 and 
Table 3. Results of the free radical scavenging activity, cytotoxicity against FL-cells and phytochemical screening of the investigated plants

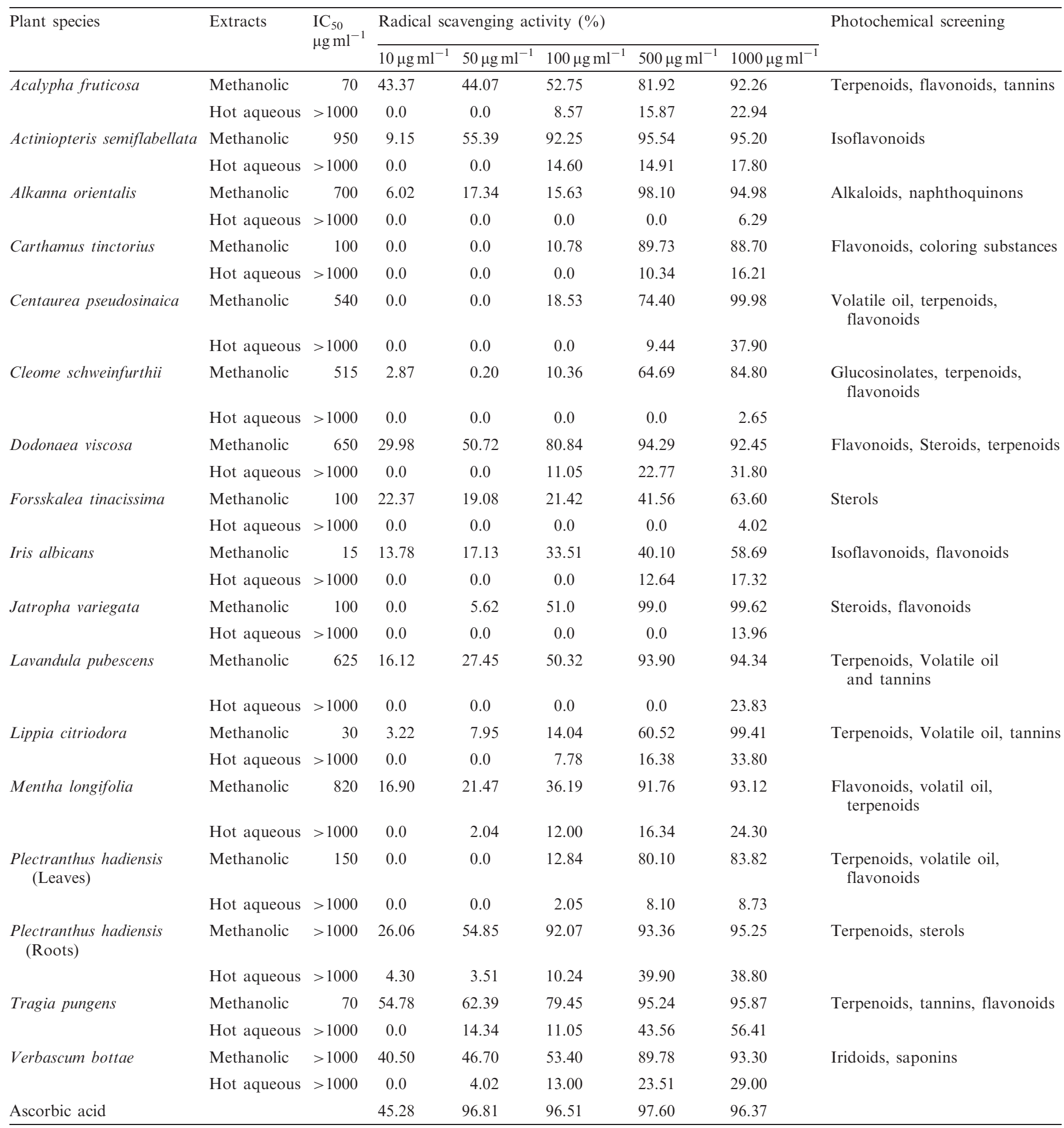

$38 \%$ at the highest concentration namely $1000 \mu \mathrm{g} \mathrm{ml}$ (Table 3).

\section{Cytotoxic Activity}

Among the 34 extracts tested for cytotoxicity against FL-cells only the methanolic extracts of A. fruticosa,
I. albicans, L. citriodora and T. pungens exhibited noticeable activities with $\mathrm{IC}_{50}$ values below $100 \mu \mathrm{g} \mathrm{ml}^{-1}$ (Table 3).

\section{Phytochemical Screening}

The results of the phytochemical screening of the investigated methanolic extracts showed the presence of 
different types of active constituents like flavonoids, terpenoids, tannins, volatile oils, etc. (Table 3).

\section{Discussion}

The results of our screening assays confirmed the use of the investigated plants in Yemeni traditional medicine. It is the first report about antimicrobial, antioxidant and cytotoxic effects of $A$. semiflabellata, $F$. tinacissima, I. albicans, J. variegata, $P$. hadiensis, $T$. pungens and $V$. bottae. Whereas other plants like $A$. fruticosa, A. orientalis, D. viscosa, L. pubescens, L. citriodora and $M$. longifolia are partly well investigated. The existing knowledge about the other investigated plants is in many cases very limited.

The antibacterial effect of $A$. fruticosa was investigated among some Indian medicinal plants (24). It was found that $A$. fruticosa was one of the most active plants tested. Other species of Acalypha like A. siamensis and A. wilkesiana also showed antimicrobial activity $(25,26)$. A search on A. guatemalensis demonstrated antioxidant and antimicrobial activity for this plant (27). The studies on $A$. wilkesiana and $A$. hispida as well as $A$. communis demonstrated the isolation of gallic acid, corilagin, geraniin and triterpenoids of cycloartane-type as compounds responsible for the observed antimicrobial activity (28,29). Flavonoids like quercetin- and kaempferol-derivatives were also identified. Thus, the estimated antimicrobial and antioxidant effects of the investigated A. fruticosa are in accordance with these data. Our phytochemical screening revealed the presence of terpenoids and flavonoids in the methanolic extract of A. fruticosa, which could be responsible for these noteworthy activities. In previous work (10), we reported about the anticancer potential effect of $A$. fruticosa against five cancer cell-lines. The methanolic extract showed a moderate cytotoxic effect against different cancer cell-lines $\left(\mathrm{IC}_{50}>50 \mu \mathrm{g} \mathrm{ml}^{-1}\right)(10)$. The cytotoxicity of $A$. fruticosa against FL-cells with $\mathrm{IC}_{50}$ of $70 \mu \mathrm{g} \mathrm{ml}^{-1}$ was in accordance with that result.

It was reported that the methanolic extract of D. viscosa has an antimicrobial effect $(30,31)$. Others described the isolation of diterpenoid- and flavonoidderivatives from $D$. viscosa (32-34). Our phytochemical screening indicated the presence of these types of compounds, which are mainly responsible for the remarkable antioxidant and antimicrobial effect of this plant.

Whereas no reports about $J$. variegata were found, the extracts of other species of Jatropha namely J. elliptica and J. gossypifolia, exhibited antibacterial effect against gram-positive bacteria $(35,36)$.

The high antibacterial effect of the investigated L. citriodora against both antibiotic susceptible and resistant Gram-positive microorganisms is due to the high content of volatile oil. In earlier studies, it was found that the extracts and isolated volatile oil from L. citriodora and other Lippia species show a strong antimicrobial activity against Helicobacter pylori (37) and against different types of bacteria and fungi (38). Unlike this result, our investigated extract of L. citriodora exhibited activity only against Gram-positive and multiresistant bacteria. No effect was observed against C. maltosa. In addition, it was demonstrated that the infusion of $L$. citriodora has a potent superoxide radical scavenging activity and a moderate scavenging activity of hydroxyl radical (39). The scavenging activity of DPPH radical in our screening was shown only at the highest concentration $\left(1000 \mu \mathrm{g} \mathrm{ml}^{-1}\right)$. This effect is due to the presence of several flavonoids and phenolic acids $(39,40)$.

For $P$. hadiensis, no reports were found. However several Plectranthus species were investigated for their antimicrobial activity against different types of microorganisms. The methanolic extract of $P$. barbatus displayed a potent antibacterial activity against grampositive bacteria including $S$. aureus (41) and a remarkable antifungal effect against $C$. albicans (42). Many diterpenoids isolated from several types of Plectranthus like $P$. fruticosus and $P$. saccatus were responsible for the antimicrobial effect (43-45). In our screening, the roots of the investigated $P$. hadiensis exhibited more antimicrobial and antioxidant activity than the leaves. There are possibilities that similar or related compounds are present in the methanolic extract, which may be responsible for the strong antibacterial and antioxidant effect.

Besides the investigation of the leaves and roots of Tragia involucrata for their potential effect in wound healing, no reports about $T$. pungens or other species of this genus exist. $T$. involucrata displayed a high antibacterial effect against different bacterial strains especially $S$. aureus $(46,47)$.

In comparison with the fact that no reports about $V$. bottae for any activity were found, $V$. macrurum and $V$. sinuatum showed antimicrobial activity $(48,49)$. The presence of saponins and irridoids as major components could be the reason for the antimicrobial activity $(50,51)$. Our phytochemical investigation showed the presence of saponins, iridoids and flavonoids, which may be responsible for the moderate antimicrobial and noteworthy antioxidant activities.

In conclusion, the results obtained in the present study are in agreement to a certain degree with the traditional uses of the plants estimated. The obtained results could form a good basis for selection of plant species for further investigation in the potential discovery of new natural bioactive compounds. A. fruticosa, C. pseudosinaica, D. viscosa, J. variegata, L. citriodora, P. hadiensis, $T$. pungens and $V$. bottae could be a source for antibacterial drugs against Gram-positive bacteria, 
especially against multiresistant microorganisms. In addition, these plants could represent striking antioxidant agents, which provide prophylaxis against various diseases like heart diseases, stroke, arteriosclerosis and cancers. The bioassay-guided fractionation procedure to characterize and isolate the antibacterial and antioxidant active constituents is needed.

\section{Acknowledgments}

The authors would like to thank Al-Saeed foundation for Science and culture, Taiz, Yemen and the University of Science and Technology, Sana'a, Yemen for the financial support to carry out this investigation.

\section{References}

1. World Health Organization. WHO Traditional Medicine Strategy 2002-2005. Geneva: World Health Organization, 2002.

2. Zhang X. Traditional medicine: its importance and protection. In: Twarog S, Kapoor P (eds). Protecting and Promoting Traditional Knowledge: Systems, National Experiences and International Dimensions. Part 1. The Role of Traditional Knowledge in Healthcare and Agriculture. New York: United Nations; 2004, 3-6.

3. Fleurentin J, Pelt J-M. Repertory of drugs and medicinal plants of Yemen. J Ethnopharmacol 1982;6:85-108.

4. Schopen A. Traditionelle Heilmittel in Jemen. Berlin: Franz Steiner Verlag GmbH, 1983.

5. Al-Dubai AS, Al-khulaidi AA. Medicinal and Aromatic Plants of Yemen (In Arabic), Sana'a, Yemen: Obadi Center for studies and Publishing, 1996.

6. El-Fiky FK, Attif O, Aboul Ela M, Gaanem N. Antimicrobial evaluation of extracts from some Yemeni plants. Alex J Pharm Sci 1995;9:35-7.

7. Awadh Ali NA, Juelich W-D, Kusnick C, Lindequist U. Screening of Yemeni medicinal plants for antibacterial and cytotoxic activities. $J$ Ethnopharmacol 2001;74:173-9.

8. Mothana RAA, Lindequist U. Antimicrobial activity of some medicinal plants of the island Soqotra. $J$ Ethnopharmacol 2005;96:177-81.

9. Mothana RAA, Mentel R, Reiss C, Lindequist U. Phytochemical screening and antiviral activity of some medicinal plants of the island soqotra. Phytother Res 2006;20:298-302.

10. Mothana RAA, Gruenert R, Lindequist U, Bednarski PJ. Study of the anticancer potential of Yemeni plants used in folk medicine. Pharmazie 2007;62:305-7.

11. Al-Fatimi M, Wuster M, Schroeder G, Lindequist U. Antioxidant, antimicrobial and cytotoxic activities of selected medicinal plants from Yemen. J Ethnopharmacol 2007;111:657-66.

12. Austin DJ, Kristinsson KG, Anderson RM. The relationship between the volume of antimicrobial consumption in human communities and the frequency of resistance. Proc Natl Acad Sci $U S A$ 1999:96:1152-6.

13. Samy RP, Ignacimuthu S, Sen A. Screening of 34 Indian medicinal plants for antibacterial properties. $J$ Ethnopharmacol 1998;62:173-81.

14. Hamil FA, Apio S, Mubiru NK, Bukenya-Ziraba R, Mosango M, Maganyi OW, et al. Traditional herbal drugs of Southern Uganda, II: literature analysis and antimicrobial assays. J Ethnopharmacol 2003;84:57-78.

15. Motsei ML, Lindsey KL, Van Staden J, Jaeger AK. Screening of traditionally used South African plants for antifungal activity against Candida albicans. J Ethnopharmacol 2003;86:235-41.

16. Joyeux M, Moitier F, Fleurentin J. Screening of antiradical, antilipoperoxidant and hepatoprotective effects of nine plant extracts used in caribbean folk medicine. Phytother Res 1995;9:228-30.

17. Azaizeh H, Ljubuncic P, Portnaya I, Said O, Cogan U, Bomzon A. Fertilization-induced changes in growth parameters and antioxidant activity of medicinal plants used in traditional Arab medicine. Evid Based Complement Alternat Med 2005;2:549-56.

18. Alma MH, Mavi A, Yildirim A, Digrak M, Hirata T. Screening chemical composition and in vitro antioxidant and antimicrobial activities of the essential oils from Origanum syriacum growing in Turkey. Biol Pharm Bull 2003;26:1725-9.

19. Willcox JK, Ash SL, Catignani GL. Antioxidants and prevention of chronic disease. Crit Rev Food Sci Nutr 2004;44:275-95.

20. Bauer AW, Kirby WMM, Sheriss JC, Turck M. Antibiotic susceptibility testing by standarised single method. Am $J$ Clin Pathol 1966;45:493-6.

21. Brand WW, Cuvelier HE, Berset C. Use of a free radical method to evaluate antioxidant activity. Food Sci Technol 1995;82:25-30.

22. Lindl T, Bauer J. Zell und Gewebekultur. Berlin: Gustav-fischerVerlag Jena, 1989, 181

23. Wagner H, Bladt S. Plants Drug Analysis: A Thin Layer Chromatography Atlas, 2nd edn. Berlin: Springer, 1996, 306-64.

24. Duraipandiyan V, Ayyanar M, Ignacimuthu S. Antimicrobial activity of some ethnomedicinal plants used by Paliyar tribe from Tamil Nadu, India. BMC Complement Altern Med 2006;17:6-35.

25. Wiart C, Hannah A, Yassim M, Hamimah H, Sulaiman M. Antimicrobial activity of Acalypha siamensis Oliv. ex Gage. J Ethnopharmacol 2004;95:285-6.

26. Akinyemi KO, Oladapo O, Okwara CE, Ibe CC, Fasure KA. Screening of crude extracts of six medicinal plants used in South-West Nigerian unorthodox medicine for anti-methicillin resistant Staphylococcus aureus activity. BMC Complement Altern Med 2005;11:5-6.

27. Navarro MC, Montilla MP, Cabo MM, Galisteo M, Cáceres A, Morales C, et al. Antibacterial, antiprotozoal and antioxidant activity of five plants used in Izabal for infectious diseases. Phytother Res 2003;17:325-9.

28. Adesina SK, Idowu O, Ogundaini AO, Oladimeji H, Olugbade TA, Onawunmi GO, et al. Antimicrobial constituents of the leaves of Acalypha wilkesiana and Aacalypha hispida. Phytother Res 2000;14:371-4.

29. Gutierrez-Lugo MT, Singh MP, Maiese WM, Timmermann BN. New antimicrobial cycloartane triterpenes from Acalypha communis. $J$ Nat Prod 2002;65:872-5.

30. Rojas A, Hernandez L, Pereda-Miranda R, Mata R. Screening for antimicrobial activity of crude drug extracts and pure natural products from Mexican medicinal plants. $J$ Ethnopharmacol 1992;35:275-83.

31. Getie M, Gebre-Mariam T, Rietz R, Höhne C, Huschka C, Schmidtke $M$, et al. Evaluation of the anti-microbial and anti-inflammatory activities of the medicinal plants Dodonaea viscosa, Rumex nervosus and Rumex abyssinicus. Fitoterapia 2003; $74: 139-43$.

32. Sachdev K, Kulshreshtha DK. Dodonic acid, a new diterpenoid from Dodonaea viscosa. Planta Med 1984;50:448-9.

33. Abdel-Mogib M, Basaif SA, Asiri AM, Sobahi TR, Batterjee SM. New clerodane diterpenoid and flavonol-3-methyl ethers from Dodonaea viscosa. Pharmazie 2001;56:830-1.

34. Getie M, Gebre-Mariam T, Rietz R, Neubert RH. Evaluation of the release profiles of flavonoids from topical formulations of the crude extract of the leaves of Dodonea viscosa (Sapindaceae). Pharmazie 2002;57:320-2.

35. de Lima MR, de Souza Luna J, dos Santos AF, de Andrade MC, Sant'Ana AE, Genet JP, et al. Anti-bacterial activity of some Brazilian medicinal plants. J Ethnopharmacol 2006;105:137-47.

36. Kumar VP, Chauhan NS, Padh H, Rajani M. Search for antibacterial and antifungal agents from selected Indian medicinal plants. J Ethnopharmacol 2006;107:182-8.

37. Ohno T, Kita M, Yamaoka Y, Imamura S, Yamamoto $T$, Mitsufuji S, et al. Antimicrobial activity of essential oils against Helicobacter pylori. Helicobacter 2003;8:207-15.

38. Oliveira DR, Leitão GG, Santos SS, Bizzo HR, Lopes D, Alviano CS, et al. Ethnopharmacological study of two Lippia species from Oriximiná, Brazil. J Ethnopharmacol 2006;108:103-8.

39. Valentão P, Fernandes E, Carvalho F, Andrade PB, Seabra RM, de Lourdes Basto M. Studies on the antioxidant activity of Lippia citriodora infusion: scavenging effect on superoxide radical, hydroxyl radical and hypochlorous acid. Biol Pharm Bull 2002;25:1324-7. 
40. Skaltsa H, Shammas G. Flavonoids from Lippia citriodora. Planta Med 1988;54:465.

41. Matu EN, van Staden J. Antibacterial and anti-inflammatory activities of some plants used for medicinal purposes in Kenya. J Ethnopharmacol 2003;87:35-41.

42. Runyoro DK, Matee MI, Ngassapa OD, Joseph CC, Mbwambo ZH. Screening of Tanzanian medicinal plants for antiCandida activity. BMC Complement Altern Med 2006;30:6-11.

43. Gaspar-Marques C, Simões MF, Duarte A, Rodríguez B. Labdane and kaurane diterpenoids from Plectranthus fruticosus. J Nat Prod 2003;66:491-6.

44. Gaspar-Marques C, Simões MF, Rodríguez B. Further labdane and kaurane diterpenoids and other constituents from Plectranthus fruticosus. J Nat Prod 2004;67:614-21.

45. Wellsow J, Grayer RJ, Veitch NC, Kokubun T, Lelli R, Kite GC, et al. Insect-antifeedant and antibacterial activity of diterpenoids from species of Plectranthus. Phytochemistry 2006;67:1818-25.
46. Perumal Samy R, Gopalakrishnakone P, Sarumathi M, Ignacimuthu S. Wound healing potential of Tragia involucrata extract in rats. Fitoterapia 2006;77:300-2.

47. Samy RP, Gopalakrishnakone P, Houghton P, Ignacimuthu S. Purification of antibacterial agents from Tragia involucrata a popular tribal medicine for wound healing. $J$ Ethnopharmacol 2006; 107:99-106.

48. Guarino C. Antimicrobial activity of Verbascum macrurum ten. (Scrophulariaceae). Boll Chim Farm 2002;141:238-42.

49. Senatore F, Rigano D, Formisano C, Grassia A, Basile A, Sorbo S. Phytogrowth-inhibitory and antibacterial activity of Verbascum sinuatum. Fitoterapia 2007;78:244-7.

50. Kalpoutzakis E, Aligiannis N, Mitakou S, Skaltsounis AL. Verbaspinoside, a new iridoid glycoside from Verbascum spinosum. J Nat Prod 1999;62:342-4.

51. Hartleb I, Seifert K. Triterpenoid saponins from Verbascum songaricum. Phytochemistry 1995;38:221-4.

Received August 24, 2007; accepted January 4, 2008 


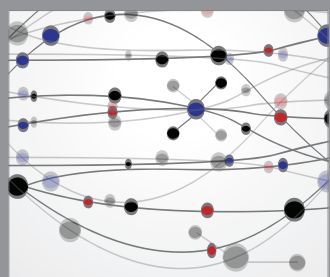

The Scientific World Journal
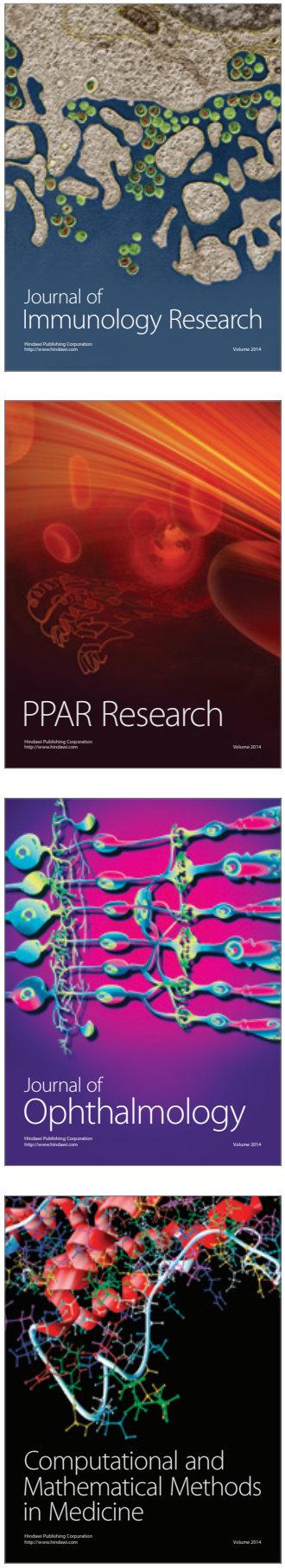

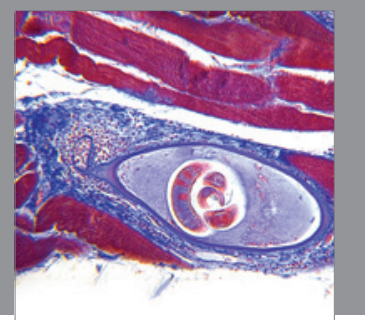

Gastroenterology

Research and Practice
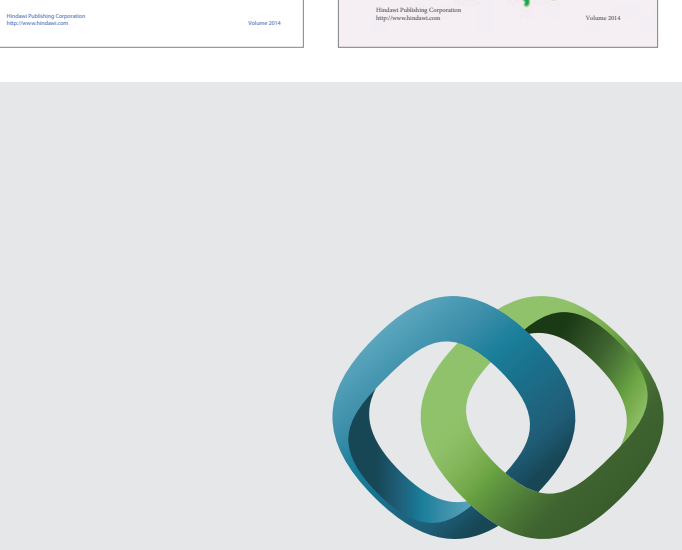

\section{Hindawi}

Submit your manuscripts at

http://www.hindawi.com
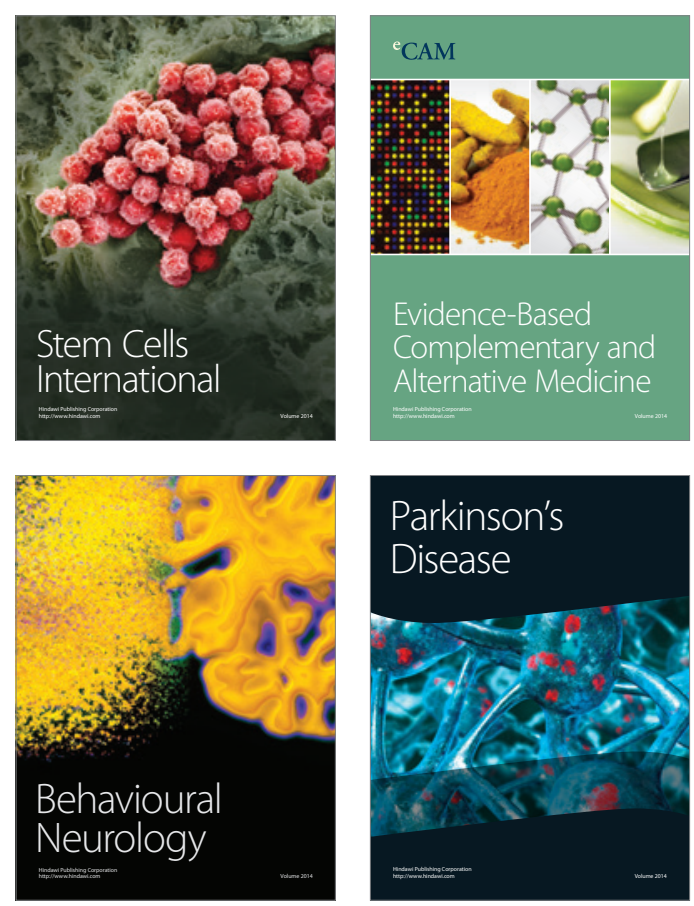

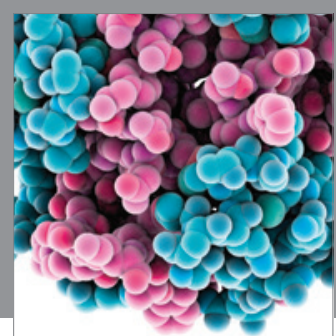

Journal of
Diabetes Research

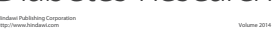

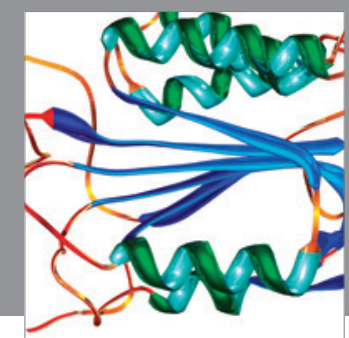

Disease Markers
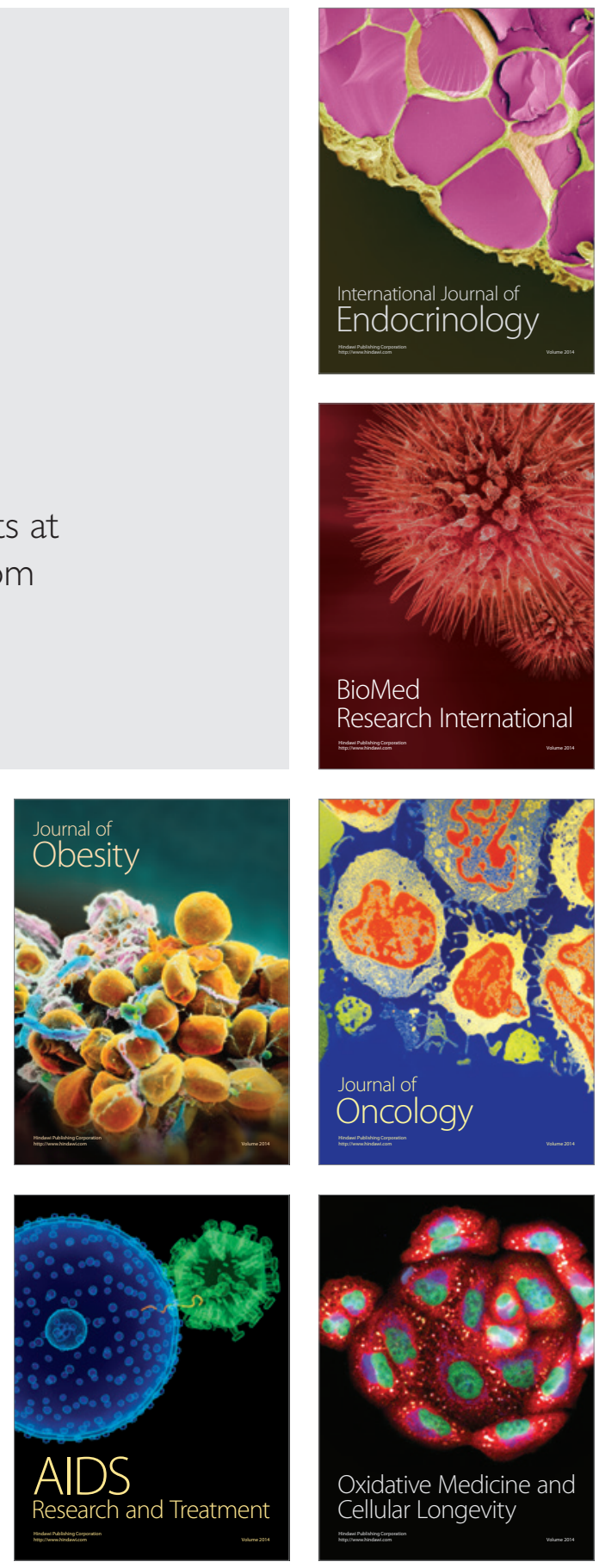